\title{
ANALISIS PERTANYAAN BACAAN DALAM BUKU TEKS BAHASA INDONESIA JENJANG SMP
}

\author{
Nia Yuniarti, M.Arifin, dan Padi Utomo \\ Program Studi Pendidikan Bahasa Indonesia \\ Jurusan Pendidikan Bahasa dan Seni \\ FKIP Universitas Bengkulu \\ niayuniartii@gmail.com
}

\begin{abstract}
Abstrak
Penelitian ini bertujuan mendeskripsikan pertanyaan bacaan yang terdapat di dalam buku teks Bahasa Indonesia jenjang SMP menggunakan dimensi kognitif Taksonomi Bloom dan berdasarkan ciri pertanyaan yang baik. Penelitian ini menggunakan metode deksriptif. Hasil penelitian menunjukkan bahwa (1) Pertanyaan bacaan yang terdapat di dalam buku teks bahasa Indonesia jenjang SMP pada tingkat kognitif memahami (C2) mendominasi dengan proporsi persentase yang jauh lebih besar dibandingkan tingkat kognitif lainnya. Kemudian, hasil tersebut belum memenuhi proporsi soal yang baik, yaitu 30\% untuk C1 dan C2, 40\% untuk C3 dan C4, 30\% untuk C5 dan C6. (2) Pertanyaan bacaan yang terdapat di dalam buku teks bahasa Indonesia jenjang SMP masih ada kategori yang belum memenuhi ciri pertanyaan yang baik yaitu terdapat di dalam ciri nomor (3) Pertanyaan hanya untuk satu masalah, nomor (5) Jawaban bukan sekadar ya atau tidak.
\end{abstract}

Kata kunci: Pertanyaan bacaan.

\begin{abstract}
The aim of this research was to describe reading questions contained in Indonesian language textbooks at the junior high school level using the cognitive dimensions of Bloom's Taxonomy and based on the characteristics of good questions. This research used descriptive method. The results of the study showed that (1) the reading questions contained in the Indonesian language textbook at the junior high school level at the cognitive level of understanding (C2) was dominated with a greater proportion compare to the other cognitive levels. Then, these results did not meet the proportion of good questions yet, such as 30\% for C1 and C2, 40\% for C3 and C4, 30\% for C5 and C6. The reading questions contained in Indonesian language textbooks at the junior high school level still have categories that have not fulfilled the characteristics of good questions which were contained in the standar character number (3) Questions are only for one problem, and number (5) Answers are not just yes or no.
\end{abstract}

Keywords: reading question, 


\section{PENDAHULUAN}

Buku teks merupakan sarana utama yang digunakan oleh pendidik selain silabus untuk pedoman proses belajar mengajar di sekolah. Menurut Tarigan (2009:13) buku teks adalah buku pelajaran dalam bidang studi tertentu, yang merupakan buku standar, yang disusun oleh para pakar dalam bidang itu buat maksud dan tujuan instruksional yang dilengkapi dengan sarana-sarana pengajaran yang serasi dan mudah dipahami oleh para pemakainya di sekolah dan perguruan tinggi sehingga dapat menunjang suatu program pengajaran. Jadi, di dalam kegiatan belajar, siswa tak sebatas mencermati apa-apa saja yang diterangkan oleh guru. Siswa juga membutuhkan referensi untuk menggali ilmu agar pemahaman siswa lebih luas sehingga kemampuannya dapat lebih dioptimalkan. Dengan adanya buku teks tersebut, siswa dituntun untuk berlatih, berpraktik, atau mencobakan teori-teori yang sudah dipelajari dari buku tersebut.

Buku teks yang digunakan dalam proses pembelajaran sangat dipengaruhi oleh perkembangan kurikulum. Saat ini, kurikulum yang berlaku merupakan kurikulum 2013 berbasis teks. Dalam kurikulum 2013 berbasis teks, pasti mempelajari berbagai teks dan membutuhkan suatu pemahaman. Salah satu cara untuk meningkatkan pemahaman siswa adalah melalui pertanyaan. Oleh karena itu, sangatlah penting suatu pertanyaan khusus nya di dalam buku teks untuk merangsang aktivitas berpikir siswa dan menumbuhkan minat dan kemampuan siswa dalam proses pembelajaran.

Pertanyaan yang terdapat di dalam buku teks salah satu nya adalah pertanyaan bacaan. Terkadang keberadaan pertanyaan di dalam buku teks masih menggunakan kalimat yang kurang jelas yang bisa mengakibatkan peserta didik menjadi bingung, dan juga terkadang masih banyak pertanyaan yang hanya membutuhkan jawaban ya atau tidak tanpa didasari alasan, sehingga tidak melatih siswa untuk berpikir. Pertanyaan tersebut bukanlah termasuk kriteria pertanyaan yang baik. Pertanyaan yang baik menurut Sardiman (2010:214-215) bahwa ada 7 ciri pertanyaan yang baik, yaitu (1) Kalimatnya singkat dan jelas, (2) Tujuannya jelas, (3) Pertanyaan hanya untuk satu masalah, (4) Mendorong anak untuk berpikir, (5) Jawaban bukan sekadar ya atau tidak, (6) Bahasa dikenal baik oleh siswa, (7) Tidak menimbulkan tafsiran ganda. Oleh sebab itu, dalam penelitian ini penulis akan meneliti pertanyaan bacaan berdasarkan ciri pertanyaan yang baik.

Pertanyaan dalam buku teks juga terkait dengan tingkat pengetahuan siswa. Berdasarkan teori Taksonomi Bloom terdapat enam tingkatan pengetahuan, diantaranya mengingat (C1), memahami (C2), menerapkan (C3), menganalisis (C4), mengevaluasi (C5), dan berkreasi (C6). Tingkat pengetahuan siswa tersebut merupakan hasil revisi yang dilakukan oleh Anderson \& Krathwol. Dalam Nurgiyantoro, (2016: 76) bahwa Anderson \& Krathwol merevisi struktur taksonomi Bloom dengan mengubah istilah jenjang-jenjang yang menyangkut substansi proses berpikir, penyederhanaan, pemilahan subkategori dan alternatif istilah, serta pemindahan posisi (urutan) jenjang berbikir. Hal inilah yang akan diteliti oleh penulis terkait dengan pertanyaan bacaan yang ada di dalam buku teks bahasa Indonesia kelas VII, VIII, dan IX berdasarkan Taksonomi Bloom. Alasan memilih ranah kognitif Taksonomi Bloom karena dalam ranah ini bisa mengukur dan mengetahui tingkat pengetahuan siswa melalui pertanyaanpertanyaan yang ada di dalam buku teks.

Buku teks yang dianalisis yakni buku teks bahasa Indonesia kelas VII yang ditulis oleh Titik Harsiati, Agus Trianto, dan E.Kosasih. Kelas VIII yang ditulis oleh E.Kosasih, dan buku teks kelas IX ditulis 
oleh Fairul Zabadi dan Sutedjo yang diterbitkan oleh Kementerian Pendidikan dan Kebudayaan Republik Indonesia. Buku tersebut dipilih dengan alasan bahwa penulis sudah mengamati buku yang digunakan di setiap sekolah. Sekolah yang menerapkan kurikulum 2013 menggunakan buku teks bahasa Indonesia yang diterbitkan oleh Kemendikbud. Buku tersebut juga tersedia di setiap perpustakaan sekolah dan juga bisa digunakan secara online dengan mengunduhnya melalui link https://www.bukupaket.com.

Artikel ini memberikan informasi tentang gambaran atau deskripsi mengenai pertanyaan bacaan dalam buku teks bahasa Indonesia jenjang SMP berdasarkan dimensi kognitif Taksonomi Bloom dan berdasarkan ciri pertanyaan yang baik.

\section{METODE}

Metode penelitian yang digunakan dalam penelitian ini adalah metode deksriptif. Data penelitian ini adalah pertanyaan-pertanyaan dalam buku teks bahasa Indonesia kelas VII yang ditulis oleh Titik Harsiati, Agus Trianto, dan E.Kosasih. Kelas VIII yang ditulis oleh E.Kosasih, dan buku teks kelas IX ditulis oleh Fairul Zabadi dan Sutedjo yang diterbitkan oleh Kementerian Pendidikan dan Kebudayaan Republik Indonesia. Sedangkan sumber data penelitian yaitu buku teks bahasa Indonesia kelas VII, kelas VIII, dan kelas IX yang diterbitkan oleh Kemendikbud.

Teknik pengumpulan data yang dilakukan dalam penelitian ini berupa dokumentasi. Instrumen yang digunakan yaitu kartu data.

Dalam penelitian ini dilakukan dengan langkah-langkah sebagai berikut:

1. Membaca seluruh pertanyaan yang berkaitan dengan bacaan di dalam buku teks bahasa Indonesia SMP kelas VII, VIII, dan IX.
2. Pertanyaan tersebut diklasifikasi berdasarkan dimensi kognitif Taksonomi Bloom dan ciri pertanyaan yang baik.

3. Melakukan penyajian data. Data yang dianalisis dalam bentuk deskripsi.

4. Menghitung persentase tingkat kognitif .

$P=$ Tingkat kognitif $\times 100 \%$ Jumlah aspek

5. Menarik kesimpulan

\section{HASIL DAN PEMBAHASAN Hasil}

Dalam penelitian ini, buku teks yang dianalisis yakni buku teks bahasa Indonesia kelas VII yang ditulis oleh Titik Harsiati, Agus Trianto, dan E. Kosasih ditemukan 79 pertanyaan bacaan yang meliputi 27 judul bacaan, dan 7 jenis teks yaitu teks deskripsi, teks cerita fantasi, teks prosedur, teks laporan hasil observasi, puisi rakyat, teks fabel, surat pribadi dan surat dinas.

Buku teks bahasa Indonesia Kelas VIII yang ditulis oleh E.Kosasih ditemukan 93 pertanyaan bacaan yang meliputi 27 judul bacaan, dan 9 jenis teks yaitu teks iklan, teks eksposisi, teks puisi, teks eksplanasi, teks ulasan, teks persuasi, teks drama, teks cerpen, buku fiksi dan non fiksi.

Buku teks kelas IX yang ditulis Fairul Zabadi dan Sutedjo ditemukan 197 pertanyaan bacaan meliputi 26 judul bacaan, dan 7 jenis teks yaitu teks puisi, teks eksemplum, teks tanggapan kritis, teks tantangan, teks diskusi, teks eksposisi, dan teks rekaman percobaan. Ketiga buku tersebut diterbitkan oleh Kementerian Pendidikan dan Kebudayaan Republik Indonesia.

Sesuai dengan fokus penelitian, pertanyaan bacaan digolongkan berdasarkan dimensi kognitif Taksonomi Bloom yang meliputi mengingat (C1), memahami (C2), menerapkan (C3), 
menganalisis (C4), mengevaluasi (C5), dan berkreasi (C6). Tidak hanya menggolongkan pertanyaan, penelitian ini juga meneliti pertanyaan bacaan di dalam buku teks bahasa Indonesia jenjang SMP berdasarkan ciri pertanyaan yang baik yang meliputi (1) Kalimatnya singkat dan jelas, (2) Tujuannya jelas, (3) Pertanyaan hanya untuk satu masalah, (4) Mendorong anak untuk berpikir, (5) Jawaban bukan sekedar ya atau tidak, (6) Bahasa dikenal baik oleh siswa, (7) Tidak menimbulkan tafsiran ganda.

1. Pertanyaan Bacaan dalam Buku Teks Bahasa Indonesia Jenjang SMP Menggunakan Dimensi Kognitif Taksonomi Bloom.

Pada pertanyaan yang terdapat di dalam judul bacaan "Kekuatan Ekor Biru Nataga" dan "Ringkasan novel cerita fantasi Anak Rembulan terdiri dari 2 nomor soal dengan kalimat perintah sebagai berikut.

1) Tulislah keajaiban tokoh dan peristiwa ajaib yang dialami tokoh pada tabel berikut!

2) Daftarlah latar apa saja yang digunakan pada cerita fantasi!

Perintah pada soal nomor 1 adalah menuliskan keajaiban tokoh dan peristiwa ajaib yang dialami tokoh pada tabel. Menyelesaikan soal nomor 1 diperlukan kemampuan untuk mengklasifikasikan keajaiban tokoh dan mengklasifikasikan peristiwa ajaib yang dialami tokoh yang tersedia di dalam tabel. Berdasarkan indikator tingkat kognitif taksonomi Bloom, kemampuan untuk mengklasifikasikan sesuatu merupakan karakteristik dari kategori memahami (C2).

Perintah pada soal nomor 2, kalimat perintahnya adalah "daftarlah latar apa saja yang digunakan pada cerita fantasi!". Menyelesaikan soal tersebut diperlukan untuk mengingat kembali materi mengenai latar apa saja yang digunakan pada cerita fantasi. Berdasarkan indikator tingkat kognitif taksonomi Bloom, kemampuan untuk mengingat kembali merupakan karakteristik dari kategori mengingat (C1).

Pada pertanyaan yang terdapat di dalam judul bacaan "Kena Batunya" terdiri atas 3 nomor soal dengan kalimat perintah sebagai berikut.

1) Bentuklah kelompok. Ubahlah cerpen tersebut ke dalam bentuk drama dengan memperhatikan struktur dan kaidahnya sebagaimana yang telah kamu pelajari terdahulu.

2) Lakukanlah silang baca dengan kelompok lain!

3) Mintalah mereka untuk memberikan tanggapan berdasarkan kreativitas pengembangan, kelengkapan struktur, serta ketepatan kaidah kebahasaannya!

Perintah pada soal nomor 1 adalah mengubah cerpen ke dalam bentuk drama dengan memperhatikan struktur dan kaidah kebahasaannya. Menjawab soal nomor 1 diperlukan kemampuan untuk membuat suatu karya. Berdasarkan indikator tingkat kognitif taksonomi Bloom, kemampuan untuk membuat suatu karya atau memproduksi merupakan karakteristik dari kategori berkreasi (C6). Selanjutnya, perintah pada soal nomor 2 adalah melakukan silang baca dengan kelompok lain. Menyelesaikan soal nomor 2 diperlukan kemampuan untuk melakukan silang baca dengan kelompok lain. Berdasarkan indikator tingkat kognitif taksonomi Bloom, kemampuan untuk melakukan sesuatu sama halnya dengan melaksanakan. Kemampuan dalam melaksanakan sesuatu merupakan karakteristik dari kategori menerapkan (C3).

Perintah pada soal nomor 3 adalah memberikan tanggapan berdasarkan 
kreativitas penembangan, kelengkapan struktur, serta ketepatan kaidah kebahasaannya. Menyelesaikan soal nomor 3 diperlukan kemampuan untuk memberikan tanggapan berdasarkan kriteria yang telah ditetapkan. Berdasarkan indikator tingkat kognitif taksonomi Bloom, kemampuan untuk memberikan tanggapan berdasarkan kriteria sama halnya dengan menilai. Kemampuan menilai merupakan karakteristik dari kategori mengevaluasi (C5). Pada pertanyaan yang terdapat di dalam judul bacaan "Si Piko, Kucingku" terdiri dari 1 nomor soal dengan kalimat perintah sebagai berikut.

\section{1) Bandingkan teks judul Si Piko Kucingku dan Kucing!}

Perintah pada soal nomor 1 adalah membandingkan teks judul Si Piko Kucingku dan Kucing. Untuk menjawab soal nomor 1 diperlukan kemampuan untuk membandingkan teks satu dengan teks lain. Berdasarkan indikator tingkat kognitif taksonomi Bloom, kemampuan untuk membandingkan dua objek merupakan karakteristik dari kategori menganalisis (C4).

\section{Pertanyaan Bacaan dalam Buku Teks Bahasa Indonesia Jenjang SMP Berdasarkan Ciri Pertanyaan yang Baik}

Berdasarkan ciri pertanyaan yang baik bahwa sudah ada memenuhi ciri pertanyaan yang baik dalam buku teks bahasa Indonesia kelas VII ditemukan di dalam judul bacaan: Pesona Pantai Senggigi, Gebyar Pementasan Tari Kolosal Ariah, Berlian Tiga Warna, Cara Memainkan Angklung, Cara Membuat Obat Tradisional Insomnia, Cara Melakukan Gerakan Tari Tor Tor, Mematikan Komputer dengan Benar, Membuat Batik Tulis, Cara Mencuci Tangan dengan Baik dan Benar, Kunang-kunang, Kucing, Si Piko Kucingku, Gurindam, Syair Perahu, Belalang
Sembah, Sesama Saudara Harus Berbagi, Kuda Berkulit Harimau, Surat Pribadi 1 dan Surat Pribadi 2, Surat Dinas 1 dan Surat Dinas 2. Kemudian, ditemukan 2 judul bacaan yang belum memenuhi kategori ciri pertanyaan yang baik. Judul bacaan tersebut Ruang Dimensi Alpha dan judul bacaan Semua Istimewa. Kedua judul bacaan tersebut belum memenuhi ciri nomor (3) Pertanyaan hanya untuk satu masalah, dan ciri nomor (5) Jawaban bukan sekedar ya atau tidak.

Dalam buku teks Bahasa Indonesia kelas VIII ditemukan di dalam judul bacaan: Teks iklan, "Segera Tambah Listrik Selagi Gratis \& Selamatkan Gigimu dari Kuman", "Manajemen Pengelolaan Sampah", teks eksposisi, "Hujan Bulan Juni," "Surat dari Ibu," "Peristiwa Pagi tadi \& Tengadah ke Bintang-bintang," "Perlawanan Ulama Pejuang Pangeran Diponegoro," Cuplikan teks "Atheis," "Internet dan HAKI," "Peringatan Hari Sumpah Pemuda," "Ketika Pangeran Mencari Isteri," "Menanti," Teks Drama, "Kena Batunya," Buku Fiksi dan Non fiksi, "Hukuman Manis Buat Arya." Kemudian, ditemukan 4 judul bacaan yang belum memenuhi kategori ciri pertanyaan yang baik. Judul bacaan tersebut Teks Iklan, "Hidup Sehat \& Bermanfaat dengan tidak merokok!," "Aku Ingin Hidup Seribu Tahun Lagi," "Perlunya Peringatan Hari Sumpah Pemuda." Judul bacaan tersebut belum memenuhi ciri nomor (5) Jawaban bukan sekedar ya atau tidak.

Dalam buku teks Bahasa Indonesia kelas IX ditemukan di dalam judul bacaan: "Puisi Jalan Kehidupan," "Jerapah dan Kura-Kura," "Mengejar Cita," "Tinggal di Rumah Susun," "Cinderella Gadis Penyabar," "Kisah Saudagar Kaya," "Orang Kepanasan," "Pesawat Kepresidenan," "Peranan Ibu dalam Keluarga," "Pengurangan Subsidi Bahan Bakar Minyak," "Perlukah Pengurangan Subsisdi BBM?," "Subsidi BBM Perlu Dikurangi," "Siswa Tidak Boleh Mengendarai Sepeda 
Motor ke Sekolah," "Percobaan Membuat Teleskop Sederhana," "Kenaikaan Tarif Tol Tidak Mempertimbangkan Hak Konsumen," "Cara Membuat Perangakap Nyamuk Sederhana," "Membuat Es Krim. Kemudian, ditemukan 9 judul bacaan yang belum memenuhi kategori ciri pertanyaan yang baik. Judul bacaan tersebut yaitu "Teks Puisi," "Putri Tangguk," "Penggembala Domba dan Serigala," "Pak Lebai," "Pak Adil Mencari Keadilan," "Desa Sukasari," "Kebijakan Mobil Murah," "Membuat Tinta Tidak Terlihat," "Membuat Termometer Sederhana." Judul bacaan tersebut belum memenuhi ciri nomor (3) Pertanyaan hanya untuk satu masalah, dan ciri nomor (5) Jawaban bukan sekedar ya atau tidak.

\section{PEMBAHASAN}

\section{Berdasarkan Dimensi Kognitif Taksonomi Bloom}

Soal-soal yang berkaitan dengan pertanyaan bacaan berdasarkan dimensi kognitif taksonomi Bloom dengan jumlah soal pada masing-masing tingkat kognitif. Selanjutnya, didapatlah persentase dalam buku teks bahasa Indonesia kelas VII, kelas VIII, dan kelas IX. Dalam buku teks kelas VII untuk kategori mengingat (C1) 3,8\%, memahami (C2) 67\%, menerapkan (C3) $5,1 \%$ menganalisis (C4) 16,5\%, mengevaluasi (C5) $6,3 \%$, berkreasi (C6) $1,3 \%$. Proporsi persentase dalam buku teks kelas VIII untuk kategori mengingat (C1) 7,4\%, memahami (C2) 48,4\%, menerapkan (C3) $17,9 \%$, menganalisis (C4) $4,2 \%$, mengevaluasi (C5) 16,8\%, berkreasi 5,3\%. Proporsi persentase dalam buku teks kelas IX untuk kategori mengingat (C1) 10,7\% memahami (C2) 47,2\%, menerapkan (C3) $2,5 \%$, menganalisis $14,2 \%$, mengevaluasi (C5) $19,3 \%$, berkreasi $6,1 \%$. Untuk melihat penyebaran soal pada masing-masing tingkat kognitif, persentase soal disajikan ke dalam bentuk grafik berikut.

\section{Gambar 1. Grafik Persentase tingkat kognitif dalam buku teks kelas VII, VIII,} dan IX

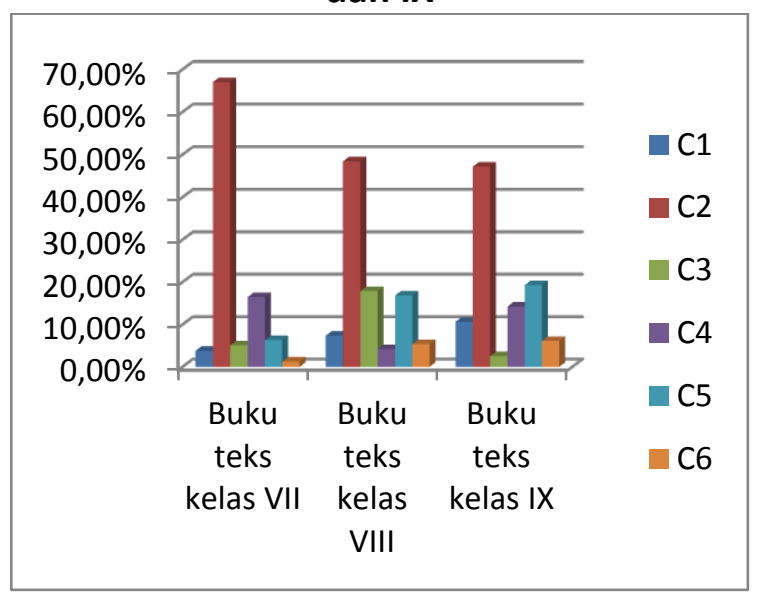

Berdasarkan grafik di atas, dalam buku teks kelas VII terjadi kenaikan yang sangat signifikan pada tingkat memahami (C2). Artinya, terjadi penumpukan pada tingkat memahami (C2). Kemudian, terjadi penurunan pada tingkat menerapkan (C3) dan kembali naik pada tingkat menganalisis (C4). Dari tingkat menganalisis (C4) terjadi penurunan kembali pada tingkat mengevaluasi (C5) dan tingkat berkreasi (C6). Proporsi tersebut tidak sesuai dengan pendapat Sudjana (2009:135) bahwa perbandingan soal yang baik untuk kriteria soal mudah, sedang dan sulit adalah 3:4:3. Perbandingan soal mudah-sedang-sulit dapat digambarkan $30 \%$ untuk tingkat C1 dan C2, 40\% untuk tingkat C3 dan C4, 30\% untuk tingkat $\mathrm{C} 5$ dan $\mathrm{C} 6$.

Hasil analisis menunjukkan total persentase pada tingkat $\mathrm{C} 1$ dan $\mathrm{C} 2$ adalah $70,8 \%$. Hal ini berarti melebih dari proporsi soal yang baik. Kemudian pada tingkat C3 dan C4 total persentase nya adalah $23 \%$. Pada tingkat ini belum mencapai proporsi soal yang baik, karena persentase nya belum mencapai atau mendekati $40 \%$. Untuk tingkat C5 dan C6 total persentase nya adalah $7,6 \%$. Proporsi pada tingkat ini sangat jauh dari proporsi soal yang baik. Selanjutnya, dalam buku teks kelas VIII terjadi kenaikan secara signifikan juga pada tingkat memahami (C2). Kemudian, 
kembali turun pada tingkat menerapkan (C3). Dari tingkat menerapkan (C3) turun lagi ke tingkat menganalisis (C4). Kemudian, naik pada tingkat mengevaluasi (C5) dan turun kembali pada tingkat berkreasi (C6).

Hasil analisis menunjukkan bahwa total persentase pada tingkat C1 dan C2 adalah $55,8 \%$. Berarti total persentase pada tingkat ini melebihi dari proporsi soal yang baik yaitu $30 \%$. Kemudian, total persentase pada tingkat C3 dan C4 adalah $22,1 \%$. Pada tingkat ini belum mencapai pada proporsi soal yang baik, karena persentase nya belum mencapai atau mendekati 40\%. Untuk tingkat C5 dan C6 total persentase nya adalah $21 \%$. Proporsi pada tingkat ini hampir mendekati pada proporsi soal yang baik.

Dalam buku teks kelas IX, terjadi kenaikan yang signifikan pada tingkat memahami (C2). Kemudian, turus secara drastis di tingkat menerapkan (C3). Dari kategori menerapkan (C3) kembali naik ke tingkat menganalisis (C4) dan mengevaluasi (C5). Kemudian, turun kembali di kategori berkreasi (C6). Hasil analisis menunjukkan bahwa total persentase tingkat C1 dan C2 adalah $57,9 \%$. Berarti total persentase pada tingkat ini melebihi dari proporsi soal yang baik. Kemudian, total persentase tingkat $\mathrm{C} 3$ dan C4 adalah 16,7\%. Pada tingkat ini belum mencapai pada proporsi soal yang baik, karena persentase nya belum mencapai atau mendekati 40\%. Untuk tingkat $\mathrm{C} 5$ dan $\mathrm{C} 6$ total persentase nya adalah $25,4 \%$. Hal ini berarti untuk tingkat C5 dan C6 hampir mendekati pada proporsi soal yang baik. Untuk keseluruhan, berdasarkan grafik yang tertera di atas menunjukkan bahwa proporsi pada tingkat mengingat (C1) pada kelas VII paling sedikit dibandingkan kelas VIII dan kelas IX. Seharusnya, pada tingkat mengingat (C1) harus lebih ditingkatkan pada buku teks kelas VII, karena pada jenjang kelas yang bawah masih diperlukan untuk meretensi materi pelajaran. Kemudian dilihat juga pada tingkat menerapkan (C3) bahwa yang paling tinggi terdapat di dalam buku teks kelas VIII dan terendah berada pada buku teks kelas IX. Seharusnya, jika kelas VIII tingkat menerapkan (C3) nya tinggi, maka kelas IX harus lebih tinggi dari kelas VIII, dikarenakan kelas IX merupakan jenjang kelas yang tinggi maka tingkat kognitif nya juga disesuaikan dengan jenjang kelas. Untuk tingkat menganalisis (C4) bahwa paling tinggi terdapat di dalam buku teks kelas VII. Seharusnya porsi persentasenya ditingkatkan pada buku teks bahasa Indonesia kelas VIII dan IX. Pada kategori mengevaluasi (C5) dan berkeasi (C6) menunjukkan bahwa terjadi peningkatan dari kelas VII, kelas VIII dan kelas IX. Hal ini baik, karena kategori ini digolongkan kategori yang sulit, sehingga mulai dari kelas VII sampai kelas IX kategori ini bertahap naik.

\section{Berdasarkan Ciri Pertanyaan yang Baik}

Dalam buku teks bahasa Indonesia jenjang SMP terdapat pertanyaan yang memenuhi ciri pertanyaan yang baik, dan yang tidak memehuhi ciri pertanyaan yang baik. Kategori yang memenuhi ciri pertanyaan yang baik harus memenuhi 7 ciri pertanyaan yang baik. Menurut Sardiman (2010:214-215) bahwa ada 7 ciri pertanyaan yang baik, yaitu (1) Kalimatnya singkat dan jelas, (2) Tujuannya jelas, (3) Pertanyaan hanya untuk satu masalah, (4) Mendorong anak untuk berpikir, (5) Jawaban bukan sekadar ya atau tidak, (6) Bahasa dikenal baik oleh siswa, (7) Tidak menimbulkan tafsiran ganda. Jika ada salah satu kriteria yang kurang, maka pertanyaan tersebut belum termasuk ciri pertanyaan yang baik.

Seperti yang terdapat di dalam buku teks bahasa Indonesia kelas VII, VIII dan IX kriteria yang tidak memenuhi ciri pertanyaan yang baik terdapat pada ciri 
nomor (3) Pertanyaan hanya untuk satu masalah, dan ciri nomor (5) Jawaban bukan sekedar ya atau tidak. Hal ini disebabkan bahwa masih banyak pertanyaan yang lebih dari satu masalah dan pertanyaan yang menjawab ya atau tidak. Seharusnya, penulis lebih memperhatikan pertanyaan yang akan dibuat. Pertanyaan lebih dari satu masalah bisa berakibat membuat siswa menjadi bingung akan pertanyaan tersebut, dan juga jika pertanyaan nya hanya membuat siswa bisa menjawab ya atau tidak tanpa adanya penjelasan, ini akan berdampak tidak melatih siswa dalam berpikir kritis dan memecahkan masalah.

\section{PENUTUP}

\section{Kesimpulan}

Berdasarkan hasil penelitian dan pembahasan bahwa 1) Pertanyaan bacaan yang terdapat di dalam buku teks bahasa Indonesia jenjang SMP pada tingkat kognitif memahami (C2) mendominasi dengan proporsi persentase yang jauh lebih besar dibandingkan tingkat kognitif lainnya, yaitu $67 \%$ pada buku teks bahasa Indonesia kelas VII, 48,4\% pada buku teks bahasa Indonesia kelas VIII, dan 47,2\% pada buku teks bahasa Indonesia kelas IX. Kemudian, proporsi dalam buku teks kelas VII pada tingkat mengingat (C1) yaitu $3,8 \%$, tingkat menerapkan (C3) $17,9 \%$, tingkat menganalisis (C4) 16,5\%, tingkat mengevaluasi (C5) 6,3\%, dan tingkat berkreasi $1,3 \%$. Proporsi dalam buku teks kelas VIII pada tingkat mengingat (C1) yaitu $7,4 \%$, tingkat menerapkan (C3) $17,9 \%$, tingkat menganalisis (C4) 4,2\%, tingkat mengevaluasi (C5) 16,8\%, dan tingkat berkreasi 5,3\%. Proporsi dalam buku teks kelas IX pada tingkat mengingat (C1) yaitu $10,7 \%$, tingkat menerapkan (C3) $2,5 \%$, tingkat menganalisis (C4) $14,2 \%$, tingkat mengevaluasi (C5) 19,3\%, dan tingkat berkreasi $6,1 \%$. Dapat disimpulkan bahwa buku teks bahasa Indonesia jenjang SMP proporsi yang dihasilkan belum mencapai pada proporsi soal yang baik. 2) Pertanyaan bacaan yang terdapat di dalam buku teks bahasa Indonesia jenjang SMP berdasarkan ciri pertanyaan yang baik masih ada beberapa pertanyaan yang belum memenuhi kriteria ciri pertanyaan yang baik, yaitu terdapat di dalam ciri nomor (3) Pertanyaan hanya untuk satu masalah dan ciri nomor (5) Jawaban bukan sekedar ya atau tidak. Jika ada salah satu kriteria ciri pertanyaan yang baik tidak ada, maka pertanyaan tersebut belum termasuk ciri pertanyaan yang baik.

\section{Saran}

Berdasarkan kesimpulan di atas, maka diajukan beberapa saran yang perlu diperhatikan oleh beberapa pihak, antara lain sebagai berikut. Bagi guru hendaknya perlu memperhatikan dan melakukan pengecekan terhadap kategori ranah pengetahuan Taksonomi Bloom pada pertanyaan bacaan dalam buku siswa yang digunakan. Sehingga apabila terjadi ketidakseimbangan antar kategori C1 (mengingat) sampai C6 (berkreasi), guru dapat mengembangkannya untuk kegiatan pembelajaran. Bagi penulis buku hasil akhir dapat dijadikan bahan masukan dalam merevisi buku selanjutnya terutama dalam pembuatan soal sehingga mencakup semua tingkatan Taksonomi Bloom dan bisa memenuhi proporsi tingkatan kognitif yang baik. Bagi mahasiswa/peneliti selanjutnya agar memperluas penelitian ini terhadap buku teks. Disarankan kepada peneliti lain untuk mengadakan penelitian lanjutan dan bisa mencari referensi lain yang berkaitan dengan pertanyaan dalam buku teks yang akan dilaksanakan selanjutnya.

\section{DAFTAR PUSTAKA}

Bukupaket. Buku Paket Kurikulum 2013. https://www.bukupaket.com (diakses Tanggal 2 Maret 2018) 
Nurgiyantoro, Burhan. 2016. Penilaian Pembelajaran Bahasa Berbasis Kompetensi. Yogyakarta:BPFE

Sardiman, A. M. 2010. Interaksi dan Motivasi Belajar Mengajar. Jakarta: Raja Grafindo Persada
Sudjana, N. 2009. Penilaian Hasil Proses Belajar Mengajar. Bandung: Remaja Rosdakarya.

Tarigan, Henry Guntur. 2005. Telaah Buku Teks Bahasa Indonesia. Bandung: Angkasa. 